\title{
INTERPRETASI HAKIM PENGADILAN AGAMA DI RIAU TENTANG KONSEP NUSYUZ DALAM PERKAWINAN
}

\author{
Aprina Chintya \\ Pengadilan Agama Rengat \\ Email: aprinachintya64@gmail.com

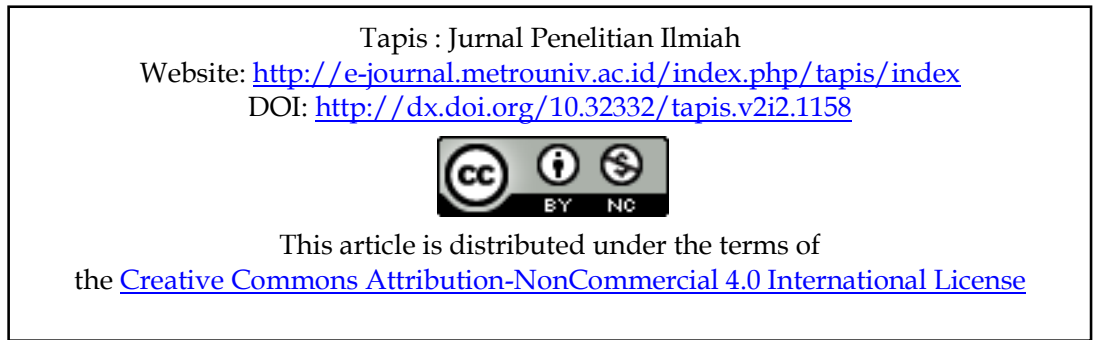

\begin{abstract}
Abstrak
Divorce is the cause of marriage breakdown according to the Islamic and Consitutional Law No. 1 of 1974 about marriage. When there is a marriage, the husband and wife both bear the rights and duties that must be fulfilled in order to build a sakinnah, mawaddah and rahmah family. When thay cannot execute their duties, it can be categorized as Nusyuz. The concept of Nusyuz is still very general and has various interpretation, depending on judge's views of who handles divorce cases in religious courts. It induces differences in defining and categorizing nusyuz among judges. This field research was conducted to discover judges' opinions at Riau religious court about the concept of nusyuz and what actions considered to be nusyuz. Observation and interview were employed to collect the data from judges and litigants purposively by using the socio-legal approach. The results of this research showed that Nusyuz means an act of wife which consciously disobey her obligation to her husband. In determining nusyuz, the judges also examined the action consideration.
\end{abstract}

Keywords: Nusyuz, Marriage, Islamic Judge, Religious Courts

Perceraian merupakan salah satu penyebab putusnya perkawinan menurut Kompilasi Hukum Islam dan UU No. 1 Tahun 1974 tentang Perkawinan. Ketika terjadi perkawinan, maka suami dan isteri sama-sama memikul hak dan kewajiban yang harus ditunaikan demi membentuk keluarga yang sakinnah, mawaddah dan rahmah. Ketika salah satu pihak tidak dapat menjalankan kewajibannya, maka hal tersebut dapat dikategorikan nusyuz. Konsep aturan mengenai nusyuz masih sangat umum dan multi tafsir, tergantung dari interpretasi hakim yang menangani kasus cerai talak di pengadilan agama. Hal ini mengakibatkan adanya perbedaan definisi dan kriteria perbuatan yang tergolong nusyuz antar hakim. Penelitian lapangan ini dilakukan untuk mengetahui pendapat para hakim pengadilan agama tentang konsep nusyuz dalam perkawinan dan perbuatan seperti apa saja yang dianggap nusyuz. Teknik pengumpulan data dalam penelitian ini menggunakan observasi dan wawancara terhadap hakim dan pihak 
berperkara di Pengadilan Agama Riau secara purposif sampling dan menggunakan pendekatan sosio legal. Berdasarkan hasil penelitian nusyuz merupakan perbuatan tidak dilaksanakannya kewajiban istri kepada suami dalam batas-batas yang dibenarkan oleh agama. Dalam menentukan nusyuz atau tidaknya seorang istri, hakim juga mempertimbangkan alasan dilakukannya perbuatan nusyuz tersebut.

Kata Kunci: Nusyuz, Perkawinan, Hakim Agama, Pengadilan Agama

\section{A. PENDAHULUAN}

Perkawinan dalam Islam merupakan suatu perbuatan yang mempunyai nilai ibadah karena setiap tindakan yang dilakukan masing-masing pasangan ketika menunaikan hak dan kewajibannya dalam suatu perkawinan adalah perbuatan yang bernilai kebaikan dan keburukan sebagaimana tujuan pernikahan sebagaimana yang tercantum dalam Undang-undang No. 1 Tahun 1974 tentang perkawinan dan Inpres Nomor 1 Tahun 1991 tentang Kompilasi Hukum Islam.

Proses membina pernikahan antara suami isteri menuju pernikahan yang sakinah, mawaddah dan warahmah serta bahagia sering tidak semudah yang dibayangkan oleh kebanyakan pasangan. Sebagian besar penyebab kemelut rumah tangga diantaranya adalah pertengkaran terus-menerus. Adanya pemicu pertengkaran ini disebabkan oleh banyak hal, misalnya karena salah satu pihak tidak melaksanakan kewajibannya dan pihak lain menuntut dilaksanakannya kewajiban tersebut. Tidak dilaksanakannya kewajiban salah satu pihak dalam kehidupan rumah tangga merupakan nusyuz, baik yang dilakukan oleh suami maupun isteri.

Ketika isteri melalaikan kewajibannya, sudah kewajiban bagi suami untuk menasehati. Namun, apabila isteri tidak dapat dinasehati atau nusyuz maka suami harus menempuh cara lain agar dapat mengingatkan isterinya. Dan yang terpenting, suami harus mengadakan perdamaian atau ishlah antara suami isteri baik dibanu oleh pihak ketiga maupun tidak. Apabila koflik dalam rumah tangga antara suami dan isteri tidak mampu diselesaikan kedua belah pihak baik melalui litigasi maupun non-litigasi, maka konflik seperti ini akan berakhir dengan perceraian di meja pengadilan.

Angka perceraian di Indonesia dari tahun ke tahun cukup tinggi, baik yang diajukan melalui cerai gugat maupun cerai talak. Berdasarkan data yang diperoleh dari laporan tahunan Badan Peradilan Agama Tahun 2017, ada 301.573 kasus cerai gugat dan 
113.937 kasus cerai talak yang masuk di pengadilan tingkat pertama. Sementara itu untuk pengadilan banding, jumlah perkara yang masuk untuk cerai gugat adalah 918 dan cerai talak sebesar $680 .{ }^{1}$

Pengadilan Tinggi Agama (PTA) Pekanbaru adalah salah satu pengadilan tinggi yang menyumbangkan angka cukup besar dalam kasus cerai talak dan cerai gugat di Indonesia. Dari ke-16 pengadilan tingkat pertama yang ada di bawah PTA Pekanbaru, pada tahun 2017 terdapat 3.053 perkara cerai talak dan 8.156 perkara cerai gugat yang masuk. $^{2}$

Khusus untuk perkara yang masuk pada tahun 2017, dari 12.779 perkara yang telah diselesaikan, perkara cerai talakemnempati urutan tertinggi setelah cerai gugat yakni sebanyak 3.053 perkara. Jumlah ini belum termasuk sisa perkara dari tahun lalu karena prosentase penyelesaian perkara baru sebesar 86,57\% (sisa perkara tahun 2017 sebanyak 1.982 perkara). ${ }^{3}$

Dalam kasus perceraian yang terjadi, khususnya cerai talak, perbuatan nusyuz tidak hanya membuat gugatan yang diajukan oleh penggugat beralasan kuat untuk dikabulkan, tapi juga berdampak pada hak isteri untuk mendapatkan nafkah iddah dan nafkah madliyyah maupun mut'ah.

Perceraian merupakan salah satu penyebab putusnya perkawinan menurut Kompilasi Hukum Islam dan UU No.1 Tahun 1974 tentang Perkawinan. Meskipun demikian nusyuz bukanlah alasan penyebab perceraian. Oleh sebab itu, nusyuz tidak dapat disepelekan karena sangat berpengaruh dalam kasus cerai talak, yakni kepada mantan isteri, terlebih bila perkaranya diputus secara verstek dan ternyata si isteri tidak melakukan nusyuz sebagaimana yang dituduhkan oleh suami sebagai penggugat.

Adanya pengaturan mengenai nusyuz dalam Kompilasi Hukum Islam (KHI) tidak secara jelas mengatur bagaimana konsep nusyuz dan batasan-batasannya. Dalam KHI hanya terdapat 5 pasal yang mengatur tentang nusyuz, yakni pasal 80, 83, 84, 149

\footnotetext{
${ }^{1}$ Direktorat Jendral Badan Peradilan Agama, “Laporan Tahunan 2017” (Jakarta: Mahkamah Agung Republik Indonesia, 2017).

2 Alimin Patawari, "Laporan Tahunan Pengadilan Tinggi Agama Pekanbaru Tahun 2017" (Pekanbaru: Pengadilan Tinggi Agama Pekanbaru, 2017), 57.

${ }^{3}$ Alimin Patawari, 59.
} 
dan 152. Dan hal itu tentu membuuhkan penjelasan yang lebih rinci lagi karena memang sejauh ini tidak ada ketentuan lain yang mengatur mengenai nusyuz.

Adapun jika selama ini hakim-hakim di Pengadilan agama menggunakan kitabkitab klasik sebagai rujukan, maka konsep nusyuz menuru satu hakim dengan hakim lain tidak akan sama, mengingat setiap hakim memiliki pengalaman, wawasan dan latar belakang yang berbeda-beda. Perbedaan ini juga akan berpengaruh terhadap putusan yang diberikan hakim.

Dengan tingginya perkara yang masuk di wilayah satuan kerja Pengadilan Tinggi Agama Pekanbaru, khususnya di Riau membuat peneliti ingin melihat interpretasi para hakim pengadilan agama di Riau tentang konsep nusyuz dalam perkawinan. Pertanyaan penelitian yang muncul dalam penelitian ini adalah:

1. Bagaimana pendapat para hakim pengadilan agama di Riau tentang konsep nusyuz dalam perkawinan?

2. Perbuatan seperti apa saja yang dianggap nusyuz oleh hakim pengadilan agama di Riau?

\section{B. METODE}

Penelitian ini adalah penelitian lapangan yang dilakukan di Pengadilan Agama Riau. Teknik pengumpulan data dalam penelitian ini menggunakan observasi dan wawancara terhadap hakim dan pihak berperkara di Pengadilan Agama Riau yang diambil melalui purposif sampling. Pendekatan yang digunakan dalam tulisan ini adalah pendekatan sosio legal, yakni sebuah pendekatan yang melihat hukum melalui penggabungan antara analisa normatif (norma-norma hukum, yuridis).

\section{HASIL PENELITIAN DAN PEMBAHASAN}

Penjelasan mengenai perkawinan dalam KHI yakni akad yang sangat kuat atau mitssaqan ghalidzan untuk mentaati perintah Allah dan melaksanakannya merupakan ibadah (Pasal 2). Mitsaqan Ghalizha merupakan komitmen yang bersungguh-sungguh dan tidak main-main. Sebentuk janji suci sekaligus ikatan sakral bukan hanya antar manusia yang terlibat, tetapi juga Allah SWT karena akan menimbulkan konsekuensi lahir dan batin, dunia dan akhirat.

Selanjutnya, dalam pasal 3 KHI dijelaskan bahwa perkawinan bertujuan untuk mewujudkan kehidupan rumah tangga yang sakinah, mawaddah, dan rahmah. Suatu 
perkawinan dibangun dengan harapan untuk mewujudkan keluarga yang bahagia, kekal dan abadi sampai akhir hayat. Akan tetapi kenyataannya perkawinan tersebut terkadang tidak selamanya berjalan sesuai dengan apa yang diharapkan. Banyak perkawinan berakhir di tengah jalan (putusnya perkawinan).

Hukum Islam telah mengatur hak dan kewajiban suami isteri sedemikian rupa, sehingga suami istri memikul kewajiban yang luhur untuk menegakan rumah tangga yang sakinah, mawad\}ah, warahmah yang menjadi basis utama bangunan suatu masyarakat. Suami istri wajib saling mencintai, menghormati, setia serta memberi bantuan lahir dan batin yang satu dengan yang lainnya.

Berkaitan dengan kedudukan sebagai suami isteri, al-Quran mengajarkan bahwa suami adalah kepala keluarga sedangkan istri adalah ibu rumah tangga. Allah berfirman:yang artinya:

"Kaum laki-laki itu adalah pemimpin bagi kaum wanita, oleh karena Allah telah melebihkan sebahagian mereka (laki-laki) atas sebahagian yang lain (wanita), dan karena mereka (laki-laki) telah menafkahkan sebagian dari harta mereka. sebab itu Maka wanita yang saleh, ialah yang taat kepada Allah lagi memelihara diri ketika suaminya tidak ada, oleh karena Allah telah memelihara (mereka). Wanita-wanita yang kamu khawatirkan nusyuznya. Maka nasehatilah mereka dan pisahkanlah mereka di tempat tidur mereka, dan pukullah mereka. kemudian jika mereka mentaatimu, Maka janganlah kamu mencari-cari jalan untuk menyusahkannya. Sesungguhnya Allah Maha Tinggi lagi Maha besar," (QS. An-Nisa: 34)

Hak dan kedudukan isteri adalah seimbang dengan hak dan kedudukan suami dalam kehidupan rumah tangga dan juga dalam pergaulan hidup bersama dalam masyarakat. Dalam konteks hubungan suami dan isteri dalam perkawinan kata nusyuz ditemukan dalam al-Quran menerangkan tentang sikap yang tidak lagi berada pada tempatnya, yang semestinya ada dan dipelihara dalam rumah tangga.

Berkaitan dengan hal tersebut negara telah membakukan peran laki-laki sebagai suami dan perempuan sebagai isteri dalam Undang-undang. Sebagaimana telah ditegaskan dalam “Undang-undang Perkawinan Nomor 1 Tahun 1974 pada Bab VI mengenai hak dan kewajiban suami isteri dan Pasal 80, 83 dan 84 Kompilasi Hukum Islam (KHI)."4

${ }^{4}$ Pasal 31 ayat (3) dinyatakan bahwa : Suami adalah kepala keluarga dan isteri ibu rumah tangga. Kemudian pada Pasal 34 ayat (1) dinyatakan bahwa : Suami wajib melindungi isterinya dan memberikan segala sesuatu keperluan hidup berumah tangga sesuai dengan kemampuannya. Dan dalam Pasal 34 ayat 
Salah satu tujuan berumah tangga dalam Islam adalah untuk memperoleh ketenangan dan ketentraman batin melalui keluarga sakinah. Oleh karena itu, Allah SWT menjadikan "mawaddah (cinta kasih) warahmah (dan rasa sayang) bagi pasangan suami isteri guna meraih ketentraman tersebut." ${ }^{5}$ Mawaddah wa rahmah ini merupakan modal dasar dalam membina keutuhan, kerukunan, dan keharmonisan berumah tangga.

Keluarga sakinah merupakan idaman dan impian bagi setiap pasangan. Hal ini terbukti apabila ditanyakan kepada pengantin baru tentang tujuan dari perkawinannya, kebanyakan setiap pengantin baru akan dengan mantap menjawab ingin membentuk keluarga bahagia, tenteram dan sejahtera, dengan kata lain keluarga yang sakinah, mawaddah, warrahmah. Akan tetapi, setelah bertahun- tahun menjalani perkawinan belum tentu cita-cita tersebut terwujud. Hal itu menunjukkan bahwa keluarga sakinah adalah hasil atau buah dari usaha dan kerja keras. Oleh karena itu, bagi setiap pasangan baik pasangan muda maupun tua yang mencita-citakan terwujudnya keluarga sakinah ini harus berusaha semaksimal mungkin karena tidak ada istilah selesai dan lelah dalam mewujudkannya. Dalam menjalani proses ini, tentu harus dilandasi dengan keimanan, ketakwaan dan ketabahan karena tanpa landasan dan komitmen yang kokoh tersebut, mustahil keluarga sakinah dapat diwujudkan.

Pada kenyataannya dalam merawat cinta kasih dan membina keharmonisan berumah tangga ini terkadang pasangan suami isteri dihadapkan pada badai dan kegalauan hidup yang dapat menghantam keutuhan rumah tangga. Badai tersebut bisa datang dari lingkungan rumah tangga itu sendiri, artinya yang bersifat intern, seperti sikap isteri yang berubah, suami cepat marah maupun anak-anak yang sulit dididik. Kemudian masalah lain yang bersifat ekstern, seperti gangguan dari tetangga, kurang baik hubungan dengan mertua ataupun kedengkian dari mitra kerja. Hal-hal tersebut bila dibiarkan berlarut-larut dan berlanjut terus-menerus akan mempengaruhi sikap masing-masing pasangan dan mengganggu keharmonisan dalam hubungan suami isteri bahkan dapat menyebabkan terjadinya tindakan sewenang-wenang antara

(2) dinyatakan bahwa: Istri wajib mengatur urusan rumah tangga sebaik-baiknya. Lihat Undang-undang Nomor 1 Tahun 1974 tentang, Perkawinan (Surabya: Gitamedia Press, 1974), 11.

${ }^{5}$ Dudung Abdul Rohman, Mengembangkan Etika Berumah Tangga Menjaga Moralitas Bangsa Menurut Pandangan Al Quran (Bandung: Nuansa Aulia, 2006), 88. 
pasangan suami dan isteri, kekerasan dalam rumah tangga, penganiayaan ataupun nusyuz dalam perkawinan.

Pasal 115 Kompilasi Hukum Islam (KHI) dan pasal 39 ayat (1) UU no.1 tahun 1974 tentang Perkawinan menjelaskan bahwa putusnya perkawinan yang disebabkan oleh perceraian hanya bisa dilakukan di hadapan sidang pengadilan, tentunya setelah pengadilan mengadakan usaha untuk mendamaikan kedua belah pihak terlebih dahulu namun tidak berhasil. Sementara itu, Pasal 39 ayat (2) UU no.1 tahun 1974 tentang Perkawinan juga menjelaskan bahwa untuk melakukan perceraian harus didasari oleh alasan yang cukup bahwa kedua belah pihak tidak dapat lagi hidup rukun sebagai suami-istri. Adapun alasan-alasan dari terjadinya perceraian sebagai mana dalam Pasal 116 UU no.1 tahun 1974 tentang Perkawinan, yakni:

1. Salah satu pihak berbuat zina atau menjadi pemabuk, pemadat, penjudi dan lain sebagainya yang sukar disembuhkan.

2. Salah satu pihak meninggalkan pihak lain selama 2 (dua) tahun berturut-turut tanpa izin pihak lain dan tanpa alasan yang sah atau karena hal lain diluar kemampuannya.

3. Salah satu pihak mendapat hukuman penjara 5 (lima) tahun atau hukuman yang lebih berat setelah perkawinan berlangsung.

4. Salah satu pihak melakukan kekejaman atau penganiayaan berat yang membahayakan pihak yang lain.

5. Salah satu pihak mendapat cacat badan atau penyakit dengan akibat tidak dapat menjalankan kewajibannya sebagai suami atau istri.

6. Antara suami dan istri terus menerus terjadi perselisihan dan pertengkaran dan tidak ada harapan akan hidup rukun lagi dalam rumah tangga.

7. Suami melanggar taklik-talak.

8. Peralihan agama atau murtad yang menyebabkan terjadinya talak.

Berdasarkan alasan-alasan terjadinya perceraian di atas, terlihat bahwa nuzyuz bukanlah alasan utama dalam perceraian. Perceraian hanya sebagai alasan penguat. Jika melihat makna nusyuz, secara kebahasaan, nusyuz dari akar kata an-nasyz atau annasyaaz yang berarti tempat tinggi atau sikap tidak patuh dari salah seorang diantara suami dan isteri atau perubahan sikap suami atau isteri. Dalam pemakaiannya, arti kata 
annusyuuz ini kemudian berkembang menjadi al'ishyaan yang berarti durhaka atau tidak patuh. Disebut nusyuz karena pelakunya merasa lebih tinggi sehingga dia tidak merasa perlu untuk patuh. 6 Secara definitive nusyuz diartikan dengan : "Kedurhakaan istri terhadap suami dalam hal menjalankan apa-apa yang diwajibkan Allah atasnya. ${ }^{7}$

Berikut ini adalah pendapat kelima responden mengenai pengertian nusyuz:

1. Nusyuz adalah kedurhakaan istri terhadap suami dan pembangkangannya atas perintah Allah dalam ketaatan terhadap suami ataupun penolakan istri atas ajakan suami untuk bersetubuh, ataupun keluarnya istri dari rumah tanpa seizin dari suami. Sebagaimana ketentuan KHI Pasal 84, Isteri dapat dianggap nusyuz jika ia tidak mau melaksanakan kewajiban-kewajiban sebagaimana dimaksud dalam pasal 83 ayat (1) kecuali dengan alasan yang sah.

2. Nusyuz adalah tindakan istri yang dapat ditafsirkan menentang atau membandel atas kehendak suami. Tentu saja kehendak suami yang tidak bertentangan dengan hukum agama. Apabila kehendak suami bertentangan atau tidak dapat dibenarkan oleh agama, maka istri berhak menolaknya.

3. Nusyuz adalah keluar dari ketaatan (secara umum) dari isteri atau suami atau keduanya.

4. Nusyuz adalah pelanggaran komitmen bersama terhadap apa yang menjadi kewajiban dalam rumah tangga baik oleh suami maupun isteri.

5. Nusyuz ialah penolakan atau pembangkangan istri terhadap suami terhadap hal-hal yang menjadikan otoritas suami untuk mendidik istrinya, seperti keluar tanpa izin suami, meninggalkan perintah Allah, seperti Shalat, atau berkhianat terhadap suaminya dalam urusan harta dan jiwa.

Dari beberapa pendapat para hakim tersebut, bisa dilihat bahwa pengertian nusyuz yang diberikan masih bersifat umum. Setidaknya nusyuz mengandung makna pembangkangan (keluar dari ketaatan), tindakan yang tidak sesuai dengan kewajiban dan merupakan tindakan yang bertentangan dengan ketentuan agama. 1353-54.

${ }^{6}$ Abdul Aziz Dahlan, Ensiklopedi Hukum Islam, 1 ed. (Jakarta: Ichtiar Baru Van Hoeve, 1996),

${ }^{7}$ Amir Syarifuddin, Hukum Perkawinan di Indonesia, 2 ed. (Jakarta: Kencana, 2006), 190-91. 
Kompilasi Hukum Islam (KHI) menjelaskan aturan mengenai persoalan nusyuz dipersempit hanya nusyuznya isteri saja akibat hukum yang ditimbulkan. Mengawali pembahasannya dalam persoalan nusyuz KHI berangkat dari ketentuan awal tentang kewajiban bagi isteri yaitu bahwa dalam kehidupan rumah tangga kewajiban utama bagi seorang isteri adalah berbakti lahir dan batin kepada suami dalam batas-batas yang dibenarkan oleh hukum Islam. Dan isteri yang dianggap nusyuz jika ia tidak mau melaksanakan kewajibannya sebagaimana yanng dimaksud walaupun dalam masalah yang menentukan ada atau tidak adanya nusyuz isteri tersebut menurut $\mathrm{KHI}$ harus didasarkan bukti yang sah. ${ }^{8}$

Ada beberapa hal yang dianggap para responden termasuk dalam kategori nusyuz, yakni:

1. Isteri tidak mentaati perintah suami, seperti tidak mengerjakan shalat, tidak menyiapkan makan, tidak membersihkan rumah, dan lain-lain (3 responden);

2. Isteri meninggalkan rumah tanpa izin suami dan bukan dnegan alasan yang dibenarkan (4 responden);

3. Isteri tidak mau disentuh oleh suami (5 responden);

4. Isteri berzina dengan laki-laki lain (5 responden);

5. Isteri menolak kediaman bersama yang disediakan oleh suami (4 responden);

6. Isteri minta cerai (1 responden);

7. Isteri mengancam suami (5 orang).

Adanya perpedaan persepsi hakim mengenai ketentuan nusyuz membuat adanya perbedaan pendapat menganai tindakan nusyuz. Meskipun demikian, dari beberapa tindakan yang dianggap sebagai tindakan nusyuz di atas, terlihat bahwa nusyuz merupakan sikap atau tindakan yang tidak berbakti kepada suami/isteri baik secara lahir maupun batin.

Pada poin ke-6 tindakan yang termasuk nusyuz di atas, yakni isteri minta cerai pada suami tidak dapat dikategorikan sebagai nusyuz karena menurut peneliti hal tersebut wajar ketika isteri dalam kondisi sulit dalam mempertahankan hubungan

\footnotetext{
${ }^{8}$ Abdurrahman, Kompilasi Hukum Islama di Indonesia, Pasal 83 Ayat 1 dan Pasal 84 Ayat 1 dan 4 (Bandung: Rineka Cipta, 2010), 91.
} 
rumah tangganya. Bahkan dalam ajaran Islam, hal tersebut dibenarkan sebagaimana yang dikenal dengan istilah khulu'.

Pada prakteknya, perbuatan nusyuz yang dilakukan oleh isteri tidak hanya satu atau dua perbuatan saja, melainkan banyak dan terakumulasi sebagai penyebab pertengkaran. Dan isteri yang seharusnya berusaha untuk berbakti lahir batin kepada suami dalam batas yang dibenarkan dalam hukum Islam justru menjadikan kelalaian dan kesalahan suami sebagai penyebab melakukan nusyuz.

Alasan kesalahan suami yang sering dijadikan alasan adalah suami tidak memberikan nafkah ekonomi yang cukup, suami memiliki wanita lain (selingkuh), dan suami melakukan kekerasan dalam rumah tangga. Adapun dalam kasus lain, ada beberapa isteri yang tidak mau berbakti lahir batin kepada suami dengan memiliki lakilaki lain karena terpaksa menikah dengan suaminya atau karena tidak kunjung dikaruniai keturunan meskipun telah bertahun-tahun menikah.

Ketidaktaatan isteri yang nusyuz akan berdampak pada pemberian nafkah, kiswah dan pemberian nafkah ekonomi bahkan tempat tinggal sebagaimana yang diatur dalam Pasal $84 \mathrm{KHI}$ yang berbunyi: "Selama isteri dalam nusyuz, kewajiban suami terhadap isterinya tersebut pada pasal 80 ayat (4) huruf a dan b tidak berlaku kecuali hal-hal untuk kepentingan anaknya."

Tidak semua kasus dimana seorang isteri tidak melaksakan kewajibannya lahir batin kepada suami dikategorikan sebagai nusyuz. Para hakim yang menjadi responden dalam penelitian ini menyatakan bahwa dilihat faktor penyabab nusyuz terlebih dahulu agar dapat dikategorikan apakah perbuatan itu benar-benar mutlak nusyuz atau bukan.

Ketika suami sudah bisa membuktikan kenusyuzan isterinya di muka pengadilan, maka hak nafkah bagi isterinya menjadi gugur. Hakim hanya memberi nafkah mu'ah saja yang besarnya ditentukan berdasarkan kemampuan suami. Meskipun demikian tidak ada hakim dalam penelitian ini ayng secara eksplisit menyebutkan isteri telah melakukan nusyuz dalam pertimbangan putusannya meskipun nusyuz itu telah jelas-jelas terbukti.

Dalam penelitian ini, peneliti mengambil putusan-putusan dan mengelompokkannya ke dalam dua kategori kelompok putusan. Yakni putusan yang mendapatkan mut'ah saja (15\%) dan tidak mendapatkan apapun (85\%). Hal ini terjadi 
karena selama persidangan isteri tidak pernah hadir dalam persidangan dan kalaupun hadir hanya hadir sebanyak satu kali dan selanjutnya tidak pernah hadir.

Adapun untuk termohon (isteri) yang telah dipanggil secara patut namun tidak pernah hadir di persidangan dan hakim menjatuhkan putusan secara verstek, maka cukup logis apabila hakim tudak memberikan apapun. Adapun bila isteri pernah hadir dalam persidangan (meskipun hanya satu kali), maka hakim akan berpendapat lain meskipun istei sudah terbukti melkaukan nusyuz.

Penentuan nusyuz tidaknya seorang isteri merupakan sesuatu yang berat bagi para hakim. Dalam mencari rujukan menentukan nusyuz tidaknya seorang isteri, paling tidak hakim harus melihat beberapa rujukan seperti yang terdapat dalam Al-Qur'an dan Sunnah serta beberapa literatur fikih klasik seperti Kitab Fiqh Sunnah, Bajuri Jilid II dan Al Mughni Ibnu Qadamah. Tidak berhenti disitu, reformulasi fiqh dalam literatur kontemporer saat ini juga bisa menjadi rujukan disamping para hakim harus memperhatikan aspek sosial budaya yang ada pada masyarakat setempat. Hakim harus berusaha menggali nilai-nilai yang hidup dalam masyarakat dan memberikan putusan yang bermutu dan memberikan nilai manfaat bagi para pencari keadilan.

Era keadilan dan kesetaraan gender yang digalakkan oleh kaum feminisme sedikit banyak memang berpengaruh terhadap cara berfikir dan perspektif para hakim dalam memeriksa suatu perkara, khususnya ketika posisi wanita dalam kasus tersebut berada pada pihak yang di injak-injak oleh sang suami. Dalam kasus perceraian, hakim harus melindungan hak-hak wanita dan anak pasca perceraian.

\section{KESIMPULAN}

Nusyuz merupakan tindakan yang tidak melaksanakan kewajibannya kepada suami dalam batas-batas yang dibenarkan oleh agama. Dalam menentukan nusyuz tidaknya seorang isteri, maka faktor-faktor atau alasan dilakukannya perbuatan nusyuz tersebut juga dipertimbangkan. Bisa saja perbuatan tersebut disebabkan oleh kesalahan suami, maka hal tersebut tidak dapat dipandang sebagai nusyuz. Sebaliknya, jika alasan dilakukannya perbuatan tersebut bukan karena kesalahan suami, maka perbuatan tersebut dapat disebut sebagai nusyuz.

Oleh sebab itu, penentuan nusyuz tidaknya seseorang tidak dapat serta merta langsung disjutifikasi tanpa melihat faktor penyebabnya dan kondisi yang 
melatarbelakanginya. Penentuan ini harus dilakukan secara teliti karena akan berdampak terhadap isteri yakni menyangkut hak nafkah dari suami.

Adanya perbedaan pendapat dalam mendefinisikan konsep nusyuz dan menentukan kriteria perbuatan yang tergolong nusyuz membuat adanya perbedaan dalam menentukan perbuatan nusyuz.

\section{DAFTAR PUSTAKA}

Abdul Aziz Dahlan. Ensiklopedi Hukum Islam. 1 ed. 4 vol. Jakarta: Ichtiar Baru Van Hoeve, 1996.

Abdurrahman. Kompilasi Hukum Islama di Indonesia, Pasal 83 Ayat 1 dan Pasal 84 Ayat 1 dan 4. Bandung: Rineka Cipta, 2010.

Alimin Patawari. "Laporan Tahunan Pengadilan Tinggi Agama Pekanbaru Tahun 2017." Pekanbaru: Pengadilan Tinggi Agama Pekanbaru, 2017.

Amir Syarifuddin. Hukum Perkawinan di Indonesia. 2 ed. Jakarta: Kencana, 2006.

Direktorat Jendral Badan Peradilan Agama. "Laporan Tahunan 2017." Jakarta: Mahkamah Agung Republik Indonesia, 2017.

Dudung Abdul Rohman. Mengembangkan Etika Berumah Tangga Menjaga Moralitas Bangsa Menurut Pandangan Al Quran. Bandung: Nuansa Aulia, 2006.

Undang-undang Nomor 1 Tahun 1974 tentang. Perkawinan. Surabya: Gitamedia Press, 1974. 